Fajar Setyawan dan Feri Setyawan/ Buana Sains Vol 19 No 2:1-6

\title{
PENGARUH SP-36 DAN ASAM HUMAT TERHADAP PERTUMBUHAN DAN PRODUKSI TANAMAN KEDELAI (Glycine max L)
}

\section{Fajar Setyawan dan Feri Setyawan}

\author{
Program Studi Agroteknologi, Fakultas Pertanian, Universitas Islam Kadiri
}

\begin{abstract}
Soybean is a food crop commodity that is needed by the Indonesian population because it is a source of vegetable protein, fat, vitamins, and minerals. To increase soybean production one of the things that needs to be done is the addition of phosphorus to increase the density of soybean seeds. The purpose of this study was to determine the effect of interactions between the administration of SP36 fertilizer doses and humic acid doses on the growth and production of soybean (Glycine max L) Dega 1 variety. Plosoklaten, Kediri Regency, with a height of 105 meters above sea level, with sandy loam soil type with soil $\mathrm{pH}$ 5. The study used factorial randomized block design (RBD) consisting of two factors, repeated 3 times. Parameters observed were Plant dried weight, plant growth rate, number of pods/plants, the weight of Seeds per plot, yield, observation data were analyzed using analysis of variance (F test). The results of the analysis of the real variance were continued with the Significant Difference test at a $5 \%$ significance level to find out the difference between treatments. The first factor is SP36 fertilizer and the second factor is humic acid. Based on the results of research that has been done, there was an interaction between the administration of SP36 fertilizer and humic acid in the parameters of plant dry weight at the age of 14 and 21, number of pods, seed weight per plot and yield., Giving fertilizer SP36 $200 \mathrm{~kg} / \mathrm{ha}$ with humic acid $50 \mathrm{~kg} /$ ha can increase crop production by $43 \%$ compared to without SP36 and without humic acid.
\end{abstract}

Keywords: Fertilizer; humic acid; production; SP-36; soybean.

\section{Pendahuluan}

Tanaman kedelai merupakan komoditas tanaman pangan yang dibutuhkan oleh penduduk Indonesia karena sebagai sumber protein nabati, lemak, vitamin dan mineral yang murah. Kebutuhan kedelai di Indonesia setiap tahun selalu meningkat seiring pertumbuhan penduduk dan perbaikan pendapatan per kapita. Namun perkembangan tanaman kedelai selama 10 tahun terakhir menunjukkan penurunan yang cukup besar, lebih dari $50 \%$, baik dalam luasan areal maupun produksinya. Pada tahun 1995, luas areal tanaman kedelai mencapai 1,4 juta ha, sedangkan pada tahun 2005, luas areal hanya 500.000 ha. Total produksi selama periode yang sama menurun dari 1,9 juta ton menjadi 700.000 ton (Adisarwanto, 2002).

Ada dua masalah yang saling terkait dan berpengaruh terhadap produktivitas tanaman kedelai, yaitu faktor teknis dan sosial-ekonomi. Faktor teknis yang berpengaruh terhadap produktivitas tanaman kedelai yaitu kualitas benih yang ditanam, pemeliharaan tanaman yang meliputi pemupukan dan pengairan 
Fajar Setyawan dan Feri Setyawan/ Buana Sains Vol 19 No 2 : 1-6

serta penanganan panen dan pasca panen. (Atman, 2009).

Untuk meningkatkan produksi kedelai salah satu hal yang perlu dilakukan yaitu penambahan unsur fosfor untuk meningkatkan massa jenis biji kedelai. Pemberian fosfor dapat dilakukan dengan pemberian bahan organik seperti asam humat dan juga bisa pemberian pupuk anorganik yaitu dengan pupuk SP36. Peningkatan ketersediaan $\mathrm{P}$ akibat pemberian bahan organik terjadi karena selama proses dekomposisi bahan organik akan dihasilkan asam humat (Asam humat memegang peranan penting pada lepasnya pengikatan $\mathrm{Al}$ dan $\mathrm{Fe}$, sehingga $\mathrm{P}$ yang semula terjerap $\mathrm{Al}$ dan $\mathrm{Fe}$ menjadi tersedia (Malcolm et al, 1979) Jayasumarta (2015) menyatakan bahwa pemupukan fosfor memberikan manfaat seperti memperbaiki pembungaan, pembuahan dan pembentukan benih, mempercepat pemasakan buah, serta mengurangi kerontokan buah. Bobot biji per tanaman digunakan untuk mengetahui hasil produksi setiap tanaman. Tanaman kedelai mampu menyerap unsur hara fosfor dengan baik didalam tanah, sehingga pemberian berbagai dosis pupuk SP-36 dalam menghasilkan bobot biji pertanaman yang berbeda-beda.

\section{Metode Penelitian}

Penelitian ini dilaksanakan pada bulan Desember 2017 hingga Februari 2018 bertempat di lahan SMKN 1 Plosoklaten, Kecamatan Plosoklaten, Kabupaten Kediri, dengan ketinggian tempat $105 \mathrm{mdpl}$, dengan jenis tanah lempung berpasir dengan $\mathrm{pH}$ tanah 5 . Alat yang digunakan dalam penelitian ini antara lain : cangkul, sabit, soil tester, meteran, gembor, ajir, ember, alat tulis, kalkulator, timbangan, kamera, dan kebutuhan alat untuk penelitian lainnya. Bahan yang digunakan dalam penelitian ini atara lain : Benih Kedelai varietas Dega 1, plat label perlakuan, pupuk SP36, Asam humat, Pestisida. Penelitian dilaksanakan secara faktorial dengan menggunakan Rancangan Acak Kelompok (RAK) terdiri dari dua faktor, diulang sebanyak 3 kali. Faktor I : Dosis pupuk SP36 (B) yang terdiri dari 4 level : B0 = Tanpa SP36, B1 = Dosis pupuk SP36 $100 \mathrm{~kg} / \mathrm{ha}$, B2 = Dosis pupuk SP36 $150 \mathrm{~kg} / \mathrm{ha}$, B3 = Dosis pupuk SP36 $200 \mathrm{~kg} / \mathrm{ha}$. Faktor II : Perlakuan Dosis Asam Humat $(\mathrm{P})$ yang terdiri dari 3 level : P0 : Tanpa Asam humat, P1 : Dosis Asam humat $25 \mathrm{~kg} / \mathrm{ha}$, P2 :Dosis Asam humat $50 \mathrm{~kg} / \mathrm{ha}$.

Parameter yang diamati Berat Kering Tanaman (g), laju pertumbuhan tanaman, Jumlah Polong/Tanaman , Berat Biji per Plot (g), bobor kering biji $\left(\mathrm{t} \mathrm{ha}{ }^{-1}\right)$. Data yang diperoleh dianalisis dengan menggunakan analisis ragam (uji $\mathrm{F}$ ) pada taraf $5 \%$ untuk mengetahui pengaruh perlakuan. Hasil analisis ragam yang nyata dilanjutkan dengan uji Beda Nyata Jujur pada taraf nyata 5 $\%$ untuk mengetahui perbedaan diantara perlakuan.

\section{Hasil dan Pembahasan}

\section{Bobot Kering Tanaman (g)}

Hasil sidik ragam menunjukkan bahwa terjadi interaksi antara perlakuan pemberian pupuk SP-36 dengan pemberian asam humat pada umur 14 dan 21 hst pada parameter berat kering tanaman. Rata - rata berat kering tanaman akibat interaksi, dapat disajikan pada Tabel 1. 
Fajar Setyawan dan Feri Setyawan/ Buana Sains Vol 19 No 2:1-6

Tabel 1. Rata-rata bobot kering tanaman kedelai varietas Dega 1 akibat pengaruh pemberian pupuk SP-36 dan asam humat.

\begin{tabular}{cllll}
\hline \multirow{2}{*}{ Perlakuan } & \multicolumn{5}{c}{ Rata-rata berat kering tanaman $(\mathrm{g})$} \\
\cline { 2 - 5 } & $14 \mathrm{hst}$ & $21 \mathrm{hst}$ & $28 \mathrm{hst}$ & $35 \mathrm{hst}$ \\
\hline B0P0 & $0.40 \mathrm{a}$ & $1.53 \mathrm{a}$ & 4.30 & 5.53 \\
B0P1 & $0.53 \mathrm{ab}$ & $1.97 \mathrm{ab}$ & 3.87 & 5.07 \\
B0P2 & $0.60 \mathrm{ab}$ & $3.77 \mathrm{~b}$ & 2.63 & 4.53 \\
B1P0 & $0.73 \mathrm{ab}$ & $2.50 \mathrm{ab}$ & 2.87 & 5.07 \\
B1P1 & $0.53 \mathrm{ab}$ & $1.63 \mathrm{a}$ & 3.63 & 7.43 \\
B1P2 & $0.60 \mathrm{ab}$ & $1.77 \mathrm{a}$ & 3.50 & 6.53 \\
B2P0 & $0.87 \mathrm{ab}$ & $1.63 \mathrm{a}$ & 3.20 & 6.73 \\
B2P1 & $0.83 \mathrm{ab}$ & $1.73 \mathrm{a}$ & 3.53 & 6.97 \\
B2P2 & $0.60 \mathrm{ab}$ & $1.83 \mathrm{a}$ & 3.97 & 9.43 \\
B3P0 & $0.73 \mathrm{ab}$ & $1.27 \mathrm{a}$ & 3.10 & 3.30 \\
B3P1 & $0.50 \mathrm{ab}$ & $0.97 \mathrm{a}$ & 2.97 & 3.43 \\
B3P2 & $1.00 \mathrm{~b}$ & $1.30 \mathrm{a}$ & 2.97 & 3.40 \\
\hline BNJ 5\% & 0.521 & 1.87 & tn & tn \\
\hline
\end{tabular}

Keterangan: Angka-angka yang didampingi huruf yang sama pada kolom yang sama menunjukkan tidak berpengaruh nyata pada uji BNJ 5\%. tn: tidak nyata, B0 :Tanpa SP36, B1 : SP36 $100 \mathrm{~kg} / \mathrm{ha}, \mathrm{B} 2$ : SP36 $150 \mathrm{~kg} / \mathrm{ha}, \mathrm{B} 3:$ SP36 $200 \mathrm{~kg} / \mathrm{ha}$. P0 : Tanpa Asam humat, P1 : Asam humat $25 \mathrm{~kg} / \mathrm{ha}, \mathrm{P} 2$ : Asam humat $50 \mathrm{~kg} / \mathrm{ha}$.

Hasil dari rata-rata berat kering tanaman dengan perlakuan pemberian pupuk SP-36 (B) dan asam humat (P), menunjukkan terjadinya interaksi pada umur 14 hst dengan rata-rata 1,00 (B3P2) dan umur 21 hst dengan ratarata 3,77 (B0P2). Menurut Wahyuningsih et al, (2016), aplikasi asam humat memberikan hasil yang terbaik pada bobot tanaman kering. Hal ini seiring dengan semakin meningkatnya ketersediaan $\mathrm{P}$ dalam tanah mempengaruhi serapan $\mathrm{P}$ oleh tanaman. Unsur hara $\mathrm{P}$ yang diserap tanaman mampu merangsang pembentukan akar sehingga pertumbuhan tanaman menjadi baik.

\section{Laju Pertumbuhan}

Hasil sidik ragam menunjukkan bahwa terjadi pengaruh yang nyata pada parameter laju pertumbuhan pada perlakuan pemberian pupuk SP36 pada umur 14-21 hst dan umur 2128 hst. Sedangkan pada pemberian asam humat tidak berpengaruh terhadap laju pertumbuhan tanaman kedelai varietas Dega 1. Rata - rata laju pertumbuhan tanaman, dapat disajikan pada Tabel 2 .

Hasil dari rata-rata laju pertumbuhan tanaman kedelai dengan perlakuan pemberian pupuk SP-36 (B0) menunjukkan pengaruh yang nyata terhadap laju pertumbuhan tanaman kedelai pada umur 14-21 hst dengan rata-rata 70,00 dan pemberian pupuk SP-36 (B1) juga menunjukkan pengaruh yang nyata terhadap laju pertumbuhan tanaman kedelai pada umur 21-28 hst dengan rata-rata 90,66 dan untuk pemberian asam humat $(\mathrm{P})$ tidak menunjukkan pengaruh yang nyata pada laju pertumbuhan tanaman kedelai varietas Dega 1. 
Fajar Setyawan dan Feri Setyawan/ Buana Sains Vol 19 No 2: 1-6

Tabel 2. Rata-rata laju pertumbuhan tanaman kedelai varietas Dega 1 akibat pengaruh pemberian pupuk SP-36 dan asam humat.

\begin{tabular}{clll}
\hline \multirow{2}{*}{ Perlakuan } & \multicolumn{3}{c}{ Rata-rata laju pertumbuhan } \\
\cline { 2 - 4 } & $14-21 \mathrm{hst}$ & $21-28 \mathrm{hst}$ & $28-35 \mathrm{hst}$ \\
\hline B0 & $70.00 \mathrm{~b}$ & $75.66 \mathrm{~b}$ & 25.00 \\
B1 & $60.66 \mathrm{~b}$ & $90.66 \mathrm{~b}$ & 20.66 \\
B2 & $51.00 \mathrm{ab}$ & $71.66 \mathrm{ab}$ & 29.00 \\
B3 & $35.66 \mathrm{a}$ & $49.00 \mathrm{a}$ & 36.00 \\
\hline BNJ 5\% & 20.47 & 24.01 & tn \\
\hline P0 & 57.33 & 80.66 & 39.66 \\
P1 & 75.33 & 105.33 & 30.33 \\
P2 & 84.66 & 101.00 & 40.66 \\
\hline BNJ 5\% & tn & tn & tn
\end{tabular}

Keterangan: Angka-angka yang didampingi huruf yang sama pada kolom yang sama menunjukkan tidak berpengaruh nyata pada uji BNJ 5\%. tn: tidak nyata, B0 :Tanpa SP36, B1 : SP36 $100 \mathrm{~kg} / \mathrm{ha}, \mathrm{B} 2$ : SP36 $150 \mathrm{~kg} / \mathrm{ha}, \mathrm{B} 3$ : SP36 $200 \mathrm{~kg} / \mathrm{ha}$. P0 : Tanpa Asam humat, P1 : Asam humat $25 \mathrm{~kg} / \mathrm{ha}, \mathrm{P} 2$ : Asam humat $50 \mathrm{~kg} / \mathrm{ha}$.

Pemberian pupuk $\mathrm{P}$ berguna bagi tanaman terutama untuk pertumbuhan dan perkembangan tanaman, karena merupakan unsur hara makro yang berpengaruh pada pertumbuhan tanaman. Hal ini sejalan dengan pernyataan Damanik et al.(2011)yang menyatakan unsur hara fosfor adalah unsur hara makro yang dibutuhkan tanaman dalam jumlah yang banyak, karena terlibat langsung pada seluruh proses kehidupan tanaman. Menurut Setyawan(2017), Bahwa pertumbuhan tanaman dipengaruhi oleh faktok lingkungan dan genetik, faktor lingkungan dan faktor genetik tersebut dapat membantu pertumbuhan. Faktor lingkungan tersebut salah satunya tentang kesuburan tanah, dimana dengan kesuburan tanah diharapkan dapat meningkatkan pertumbuhan, Apalagi dengan pemberian bahan organik dan B. subtilis dapat memberi pengaruh positif terhadap pertumbuhan dan hasil tanaman.

Sedangkan asam humat tidak berpengaruh pada laju pertumbuhan diduga karena asam humat merupakan bahan organic yang berfungsi untuk memperbaiki sifat-sifat pada tanah bukan pada tanaman itu sendiri. Hal ini sejalan dengan pernyataan Lingga (2004), yang menyatakan bahwa bahan organic memegang peranan penting di dalam tanah terutama dalam hal memperbaiki struktur tanah, menaikkan daya serap tanah terhadap air, menaikkan kondisi di dalam kehidupan di dalam tanah, dan sebagai sumber zat makanan bagi tanaman.

\section{Jumlah Polong/Tanaman}

Hasil sidik ragam menunjukkan bahwa terjadi interaksi antara perlakuan pemberian pupuk SP-36 dengan pemberian asam humat pada jumlah polong/tanaman. Rata - rata jumalah polong / tanaman akibat interaksi, dapat disajikan pada Tabel 3. Hasil dari rata-rata jumlah polong/tanaman dengan perlakuan pemberian pupuk SP-36 (B) dan asam humat $(\mathrm{P})$, menunjukkan terjadinya interaksi dengan rata-rata 36 (B3P2). Menurut Sutejo (1999), pemupukan P dapat memperbaiki pertumbuhan generatif terutama pembentukan 
Fajar Setyawan dan Feri Setyawan/ Buana Sains Vol 19 No 2 : 1-6

bunga, buah, dan biji pada tanaman polong-polongan. Sedangkan asam humat berperan untuk membantu melepaskan unsur $\mathrm{p}$ dari jelatan $\mathrm{Al}$ da Fe di dalam tanah. Hal ini sejalan dengan pernyataan Damanik et al. (2011), yang menyatakan bahwa penambahan asam humat dapat membantu penyerapan $\mathrm{P}$ dari dalam tanah. Asam humat yang diberikan ke tanah akan melepaskan ion organic yang membuat $\mathrm{P}$ yang terikat oleh logam tanah terlepas dari ikatannya sehingga menjadi tersedia untuk tanaman.

\section{Bobot Biji per Plot (g)}

Hasil sidik ragam menunjukkan bahwa terjadi interaksi antara perlakuan pemberian pupuk SP-36 dengan pemberian asam humat pada berat biji/plot. Rata - rata bobot biji per plot akibat interaksi, dapat disajikan pada Tabel 3.

Hasil dari rata-rata bobot biji per plot dengan perlakuan pemberian pupuk SP-36 (B) dan asam humat (P), menunjukkan terjadinya interaksi dengan rata-rata 1136,67 (B3P2). Hal ini dikarenakan unsur $\mathrm{P}$ sangat penting bagi pembentukan masa berat biji pada masa generative. Ini sesuai dengan pernyataan (Winarso, 2005) yang menyatakan apabila tanaman sudah memasuki fase generative sebagian besar P dimobilisasi ke biji dan buah atau bagian generative yang lain. Serapan hara P saat vegetative yaitu mulai perkecambahan hingga berbunga, total serapan tidak lebih dari $10 \%$, sehingga $90 \%$ unsur hara $\mathrm{P}$ selama pertumbuhan diserap pada masa generatif. Sedangkan menurut Minardi (2010), pemberian asam humat ternyata memacu pertumbuhan, berat kering tajuk serta akar.

\section{Hasil Panen}

Hasil sidik ragam menunjukkan bahwa terjadi interaksi antara perlakuan pemberian pupuk SP-36 dengan pemberian asam humat pada hasil panen. Rata - rata hasil panen akibat interaksi, dapat disajikan pada Tabel 3.

Hasil dari rata-rata hasil panen ton per ha dengan perlakuan pemberian pupuk SP-36 (B) dan asam humat (P), menunjukkan terjadinya interaksi terbaik dengan rata-rata 2,266 (B3P2). Ini terjadi karena fungsi $\mathrm{P}$ salah satunya sebagai pembentukan masa biji sehingga hasil biji per ha dapat dimaksimalkan karena ditunjang oleh fungsi $\mathrm{P}$ itu sendiri. Secara umum, fungsi $\mathrm{P}$ dalam tanaman adalah merangsang pertumbuhan akar, mempercepat serta memperkuat tanaman muda menjadi tanaman dewasa dan menaikkan prosentase bunga menjadi buah/biji. Sedangkan asam humat sendiri menurut Heil (2004) memainkan peran aktif dalam memacu pertumbuhan secara langsung melalui peningkatan laju fotosintesis, pertumbuhan, dan hasil tanaman.

\section{Kesimpulan}

Terjadi interaksi antara pemberian pupuk SP36 dan asam humat pada parameter bobot kering tanaman, jumlah polong, bobot biji per plot dan hasil panen., Pemberian pupuk SP36 $200 \mathrm{~kg} / \mathrm{ha}$ dengan asam humat $50 \mathrm{~kg} / \mathrm{ha}$ dapat meningkatkan produksi tanaman sebesar 43\% dibandingkan dengan tanpa SP36 dan asam humat.

Pemberian pupuk SP36 secara tunggal memberikan pengaruh terhadap parameter laju pertumbuhan 14-21 hst dan 21-28 hst. Pemberian asam humat secara tunggal tidak memberikan pengaruh terhadap semua parameter pertumbuhan dan parameter panen. 
Fajar Setyawan dan Feri Setyawan/ Buana Sains Vol 19 No 2 : 1-6

Tabel 3. Rata-rata jumlah polong/tanaman, Bobot biji per plot dan hasil panen pada tanaman kedelai varietas Dega 1 akibat interaksi pemberian pupuk SP-36 dan asam humat.

\begin{tabular}{clll}
\hline Perlakuan & $\begin{array}{l}\text { Jumlah } \\
\text { polong/tanaman }\end{array}$ & $\begin{array}{l}\text { Berat biji/plot } \\
(\mathrm{g})\end{array}$ & $\begin{array}{l}\text { Hasil panen } \\
\text { ton/ha }\end{array}$ \\
\hline B0P0 & $19.97 \mathrm{a}$ & $641.00 \mathrm{a}$ & $1.276 \mathrm{a}$ \\
B0P1 & $22.13 \mathrm{ab}$ & $704.67 \mathrm{ab}$ & $1.406 \mathrm{ab}$ \\
B0P2 & $22.43 \mathrm{ab}$ & $718.00 \mathrm{ab}$ & $1.433 \mathrm{ab}$ \\
B1P0 & $23.73 \mathrm{~b}$ & $759.00 \mathrm{~b}$ & $1.513 \mathrm{~b}$ \\
B1P1 & $23.40 \mathrm{~b}$ & $747.67 \mathrm{ab}$ & $1.490 \mathrm{~b}$ \\
B1P2 & $25.47 \mathrm{~b}$ & $814.33 \mathrm{~b}$ & $1.626 \mathrm{~b}$ \\
B2P0 & $25.97 \mathrm{bc}$ & $829.33 \mathrm{bc}$ & $1.656 \mathrm{bc}$ \\
B2P1 & $25.67 \mathrm{~b}$ & $821.33 \mathrm{~b}$ & $1.636 \mathrm{~b}$ \\
B2P2 & $29.70 \mathrm{~cd}$ & $948.67 \mathrm{c}$ & $1.896 \mathrm{~cd}$ \\
B3P0 & $29.13 \mathrm{c}$ & $931.67 \mathrm{c}$ & $1.860 \mathrm{c}$ \\
B3P1 & $32.80 \mathrm{~d}$ & $1034.00 \mathrm{~cd}$ & $2.080 \mathrm{~d}$ \\
B3P2 & $36.00 \mathrm{~d}$ & $1136.67 \mathrm{~d}$ & $2.266 \mathrm{~d}$ \\
\hline BNJ 5 \% & 3.28 & 107.11 & 209.38 \\
\hline
\end{tabular}

Keterangan: Angka-angka yang didampingi huruf yang sama pada kolom yang sama menunjukkan tidak berpengaruh nyata pada uji BNJ 5\%., B0 :Tanpa SP36, B1 : SP36 $100 \mathrm{~kg} / \mathrm{ha}, \mathrm{B} 2$ : SP36 $150 \mathrm{~kg} / \mathrm{ha}, \mathrm{B} 3$ : SP36 $200 \mathrm{~kg} / \mathrm{ha}$. P0 : Tanpa Asam humat, P1 : Asam humat $25 \mathrm{~kg} / \mathrm{ha}, \mathrm{P} 2$ : Asam humat $50 \mathrm{~kg} / \mathrm{ha}$.

\section{DAFTAR PUSTAKA}

Adisarwanto, T. 2002. Budidaya Kedelai Tropika. Penebar Swadaya. Jakarta.

Atman. 2009. Strategi Peningkatan Produksi Kedelai di Indonesia. Jurnal Ilmiah. Tambua. Jakarta. 8:39-45.

Damanik, M. M. B., B. E. Hasibuan, Fauzi, Saifuddin dan $\mathrm{H}$. Hanun. 2011. Kesuburan Tanah dan Pemupukan. USU Press. Medan.

Heil, W., 2004. Reference Ranges for Adults and Children (PreAnalitycal Considerations). Roche Diagnotic GmbH. P: 26-27.

Jayasumarta, D. 2015. Pengaruh Sistem Olah Tanah dan Pupuk P Terhadap Pertumbuhan dan Produksi Tanaman Kedelai (Glycine max L). J. Ilmu Pertanian “AGRIUM". 17(3): 41-48
Lingga, P. dan Marsono. 2004. Petunjuk Penggunaan Pupuk. Penebar Swadaya. Jakarta

Malcolm, R.E., and Vaughan, D. 1979. Humic Subtances and Phophatase Activities in Plant Tissues. Soil Biol. Biochem. 11: 253-259.

Setyawan, F. 2017. Pengaruh Bacillus subtilis dan Bahan Organik Terhadap Pertumbuhan dan Produksi tanaman Kedelai ( Glycine MaxL.). J. Hijau Cendekia. 2 (1) : $21-28$.

Wahyuningsih., E. Proklamaningsih, M. Dwiati. 2016. Serapan Fosfor dan Pertumbuhan Kedelai (Glycine Max) pada Tanah Ultisol dengan Pemberian Asam Humat. J. Fakultas Biologi. 1 (1) 68-69.

Winarso. 2005. Pengertian dan Sifat Kimia Tanah. Gajah Mada University Press. Yogyakarta. 